L.A. FREEWAY 



\section{DAVID BRODSLY}

\section{L.A. FREEWAY}

A N

A $P \quad P$

$\begin{array}{lllll}C & \text { I } & A & \mathrm{~T} & \text { I }\end{array}$

E

E $\quad S \quad S \quad A \quad Y$ 
UNIVERSITY OF CALIFORNIA PRESS

BERKELEY AND LOS ANCELES, CALIFORNIA

UNIVERSITY OF CALIFORNIA PRESS, LTD.

LONDON, ENGLAND

COPYRICHT O 1981

BY THE REGENTS OF THE UNIVERSITY OF CALIFORNIA

PRINTED IN THE UNITED STATES OF AMERICA

Grateful acknowledgment is due the following publishers for permission to include excerpts from:

"Atlantis" from The Bridge by Hart Crane. Copyright 1933, O 1958, 1970 by Liveright Publishing Corporation. Reprinted with the permission of Liveright Publishing Corporation.

Lyric from the song "The Cement Octopus," words and music by Malvina Reynolds. Copyright 01964 Schroeder Music Co. (ASCAP). Reprinted by permission.

"Freeway Problems" from Freeway Problems and Other Poems by Lawrence P. Spingarn. Copyright $O 1970$ by Lawrence $P$. Spingarn. Reprinted with the permission of the author.

Lyric from "Traffic Jam" by James Taylor. Copyright $O 1977$ by Country Road Music, Inc. Used by permission, all rights reserved.

\section{Library of Congress Cataloging in Publication Data}

Brodsly, David.

L.A. freeway, an appreciative essay.

Bibliography-

includes index

1 Express highways-California-Los Angeles metropolitan area-History.

2. Los Angeles metropolitan area-Social conditions. 3. Urban

transportation-California - Los Angeles metropolitan area-History. I. Title.

HE356.5.L7B76 $388.4^{\prime} 11^{\prime} 0979493$

$80-29620$

ISBN 0-520-04068-6 
For my parents, William and Edith Brodsky, and for Greg Erlandson 
